\title{
PENANAMAN PERILAKU ANTI-PLAGIASI DALAM PERKULIAHAN WRITING FOR ACADEMIC ASSIGNMENTS
}

\author{
Ari Purnawan \\ Jurusan Pendidikan Bahasa Inggris FBS UNY \\ email: ari_purnawan@uny.ac.id
}

\begin{abstract}
ABSTRAK
Artikel ini bertujuan menanamkan sikap anti-plagiasi di kalangan mahasiswa di Jurusan Pendidikan Bahasa Inggris FBS UNY yang tercermin pada pendapat dan hasil tulisan mereka. Penelitian ini dilakukan di sekelompok mahasiswa Jurusan bahasa Inggris UNY Semester IV yang menempuh perkuliahan Writing for Academic Assignments tahun akademik 2015/2016 sebanyak 1 kelas (20 orang, terdiri dari 12 perempuan dan 8 laki-laki). Data diambil dengan teknik observasi terhadap proses tindakan, pemberian kuesioner untuk menjajagi pendapat dan sikap, wawancara untuk keperluan penajaman atau penggalian informasi, dan unjuk kerja menulis karya ilmiah berupa essay dan proposal penelitian. Penelitian ini mampu mengurangi secara signifikan jumlah pelanggaran yang dilakukan dalam penulisan sumber, dari $85 \%$ di awal penelitian menjadi $40 \%$ di akhir Siklus 1, dan $20 \%$ di akhir Siklus 2.
\end{abstract}

Kata Kunci: anti-plagiasi, kutipan, parafrase, rangkuman

\section{FOSTERING ANTI-PAGIARISM ATTITUDE IN THE SUBJECT OF WRITING FOR ACADEMIC ASSIGNMENTS}

\begin{abstract}
The article disseminates the results and findings of a study aiming to foster the attitude towards anti-plagiarism among students of the English Education Department of FBS, UNY, as reflected on their opinions and writing products. The study was implemented on a group of semester IV students of the English Education Department of UNY in the academic year 2015/2016 taking the course of Writing for Academic Assignments. The group consisted of 20 students, 12 female and 8 male. The data were collected through a series of observation on the action process, a questionnaire on the respondents' opinions and ideas, interviews for deeper facts and information, and tasks of writing academic essays and research proposal mini project.

The action research stages were carried out through two cycles, each of which was completed in 7 class sessions. This study finally was able to decrease the number of violations and plagiarism in a significant quantity, from initially $85 \%$ to $40 \%$ by the end of Cycle 1 and to $20 \%$ by the end of the study.
\end{abstract}

Keywords: anti-plagiarism, quotation, paraphrase, summary

\section{PENDAHULUAN}

Selama ini salah satu keluhan yang sering muncul di kalangan dosen perguruan tinggi maupun praktisi kegiatan akademik adalah tingginya gejala plagiasi (plagiarism) dalam segala bentuknya. Secara sederhana plagiasi sering diartikan sebagai tindakan yang melanggar batas kejujuran dalam berperilaku ilmiah, utamanya dalam perilaku mengambil -baik sebagian maupun seluruhnya- hak atau karya pemikiran, gagasan, tulisan, dan penemuan orang lain untuk keperluan keperluan yang menguntungkan diri sendiri. Frekuensi keluhan ini muncul semakin tinggi seiring dengan hadirnya berbagai sifat dan variasi penugasan perkuliahan di Jurusan pendidikan bahasa Inggris yang menuntut dibuatnya ekspresi pemikiran, gagasan, dan karya yang harus dibuat secara tertulis sebagai bagian dari kegiatan belajar dan pengembangan diri. 
Gejala timbulnya plagiasi dalam segala bentuknya ini semakin sering muncul dalam berbagai peristiwa dan tahap belajar seorang mahasiswa. Dalam penulisan tugas harian perkuliahan saja, misalnya, terjadi proses plagiasi, baik disadari maupun tidak oleh pelakuknya. Pengutipan sumber secara ilegal, peminjaman ide dalam jumlah berlebihan, dan bahkan pengambilan karya secara utuh sering dijumpai dalam tumpukan karya tulis, tugas, dan bahkan skripsi yang dibuat mahasiswa. Tidak jarang dijumpai pula bentuk plagiasi karya yang lebih parah, yaitu ketika ada mahasiswa yang mengambil karya tulis orang lain secara utuh dan diakui sebagai karya buatannya sendiri.

Keprihatinan semacam ini membawa pada situasi dibutuhkannya solusi yang dapat meminimalkan tindak ketidakjujuran akademik seperti di atas. Perlu dilakukan investigasi tentang fenomena plagiasi di kalangan mahasiswa ini, sehingga dapat dilakukan tindakan yang tepat sebagai alat untuk mencegah atau mengubah perilaku yang tidak terpuji ini. Oleh karena ini, penelitian ini menjadi sangat urgen untuk dilakukan. Dengan penelitian ini, dapat diketahui beberapa aspek penyebab timbulnya gejala plagiasi, misalnya apakah terjadi karena disengaja atau karena ketidaktahuan mahasiswa tentang batas legal peminjaman gagasan orang lain, alasan yang mendorong timbulnya gejala ini menjadi masif, kemudian dapat dilakukan langkah nyata berupa serangkaian action yang terencana dan terkontrol dalam siklus penelitian tindakan kelas dan kemudian dapat pula dirumuskan tindakan preventif dan kuratif yang diharapkan dapat dijadikan embrio bagi terciptanya sistem pembelajaran yang mengedepankan aspek kejujuran dan anti-plagiasi sebagai salah satu menu utamanya.

Permasalahan yang dikaji solusinya dalam penelitian ini dapat diformulasikan dalam dua hal sebagai berikut: (1) faktor penentu timbulnya plagiasi di kalangan mahasiswa dan (2) usaha yang dilakukan untuk mengembangkan sikap anti-plagiasi bagi mahasiswa. Secara teoritis, karya ini dapat menjadi acuan bagi pihak lain atau kalangan akademisi yang berminat pada upaya pengembangan sikap anti-plagiasi atau berbagai tindak ketidakjujuran lainnya yang berkembang di kalangan sebagian maha- siswa. Secara praktis, penelitian ini bermanfaat ganda: a). bagi mahasiswa yang menjadi subjek penelitian, mereka akan dapat menerima perlakuan pengembangan sikap anti-plagiasi secara langsung dan b). bagi dosen/penyusun silabus perkuliahan atau pengembang kurikulum, yang dapat menggunakan hasil penelitian ini sebagai salah satu bahan pertimbangan untuk pengembangannya.

\section{Menulis di Perguruan Tinggi}

Menulis adalah salah satu keterampilan berbahasa yang diperlukan saat seorang pelajar ingin menguasai bahasa asing. Sebagai keterampilan produktif, menulis menuntut penguasaan skill dan elemen bahasa yang lainnya seperti kosa kata dan struktur kalimat. Untuk itu, keterampilan menulis ini sering dianggap keterampilan berbahasa tingkat lanjut karena tuntutan di tingkat gramatis, semantis, dan wacana.

Dengan tuntutan menulis yang demikian tinggi, keterampilan berbahasa ini hanya bisa dikuasai secara gradual dan mempersyaratkan kemampuan serta keterampilan lainnya. Menurut Menary (2007), menulis sebenarnya mentransformasi kemampuan kognitif, menciptakan dan memanipulasi kata dan kalimat yang sesuai dengan fungsi-fungsi gerak tubuh dan syaraf. Senada dengan ini, Oatley dan Djikic (2008) mendefinisikan kegiatan menulis sebagai pemikiran yang menggunakan kertas dan media lain untuk mengeluarkan dan memanipulasi ungkapan-ungkapan simbolis. Dengan demikian, menulis tidak semata kegiatan motorik tangan dan jari tetapi juga melibatkan kemampuan dan keterampilan kognitif dalam mengungkapkan dan memanipulasi atau mentransformasi perasaan, gagasan, dan imajinasi menjadi simbol tulis. Ini bukan tugas yang mudah karena melibatkan integrasi aspek-aspek motorik, kognitif, dan kadang afektif.

Program pengajaran menulis di perguruan tinggi sudah banyak dijalankan di lembagalembaga pendidikan tinggi dan universitas. Transisi dari sekolah menengah atas ke perguruan tinggi mensyaratkan pengetahuan akan konvensi, aturan, dan etika dalam menulis di dunia akademik (Hjortshoj, 2009). Ini tentunya tidak mudah bagi para mahasiswa karena ada 
sikap, strategi, dan teknik yang harus dikuasai untuk menunjang keberhasilan mereka dalam tugas menulis di perguruan tinggi. Sebagai seorang akademisi, mahasiswa dituntut untuk bersikap jujur, terbuka, dan adil dalam setiap karya-karyanya. Untuk mendukung sikap itu diperlukan strategi dan teknik menulis yang harus mereka kuasai supaya mereka terhindar dari sikap tidak jujur dan tidak adil. Terlebih lagi, mereka juga dituntut untuk bisa berpikir kritis dalam menganalisis suatu gagasan dan memecahkan suatu permasalahan akademik (Dong \& Yue, 2015). Masuknya keterampilan menulis dalam struktur kurikulum membuat 'menulis' menjadi vital dalam perkembangan studi mahasiswa di perguruan tinggi.

\section{Plagiasi dalam Karya Tulis}

Kegiatan akademik menulis, atau menuangkan gagasan dan melaporkan pemikiran dalam bentuk tulisan, dilakukan dengan serangkaian peraturan yang mengikat pelaku penulisan. Beberapa aspek penulisan yang penting, selain menggunaan bahasa, tata tulis, dan tata bahasa adalah menjaga agar tulisan tersebut bebas dari tuduhan penjiplakan, plagiasi, atau peminjaman hasil pemikiran orang lain secara tidak sah. Peraturan, kode etik, dan serangkaian regulasi yang menyangkut tindak pengambilan sebagian maupun seluruhnya dari karya orang lain ini sebenarnya sudah sangat banyak. Kementerian Pendidikan Nasional bahkan juga mengeluarkan peraturan tentang ini, yaitu Peraturan Mendiknas no 17 Tahun 2010 tentang Pencegahan dan Penanggulangan Plagiat di Perguruan Tinggi. Dalam Permendiknas tersebut dirumuskan plagiasi ini dalam definisinya: plagiat adalah perbuatan secara sengaja atau tidak sengaja dalam mengutip sebagian atau seluruhnya karya pihak lain dan diakui sebagai karyanya sendiri dan dengan tanpa ada penyebutan sumber secara memadai.

Secara umum, plagiasi dapat disamakan dengan tindak tidak legal dalam pengambilan pemikiran orang lain. Bailey (2011) secara jelas menyebutkan bahwa plagiasi ini merupakan tindakan mengambil gagasan atau kata-kata dari sebuah sumber tanpa memberikan kredit kepada pemilik gagasan atau tanpa ada pengakuan tentang hal ini. Hal ini bahkan dapat dikategorikan sebagai tindak pencurian, atau dalam istilah Bailey adalah kejahatan akademik (academic crime).

Dengan demikian jelas bahwa dalam kegiatan menulis sebuah karya, seseorang tidak dapat dengan semaunya mengutip dan mengambil buah pikiran orang lain. Hal ini karena sebenarnya hasil pemikiran atau gagasan seseorang yang dituangkan ke ranah publik adalah tetap menjadi hak atau property dari penulisnya, semacam kekayaan intelektual yang tidak bisa dengan mudah diambil begitu saja. Orang yang pertama kali mengungkapkan sebuah gagasan atau hasil pemikiran ke publik, dengan demikian, akan menjadi pemilik gagasan tersebut. Orang lain yang akan ikut menggunakan gagasan tersebut, meskipun hanya untuk memperkuat sebuah argumentasi, tetap harus mematuhi aturan mainnya: mencantumkan sumber secara memadai dan jelas.

Banyak referensi yang menyebutkan berbagai tindak yang dapat dikategorikan dalam pelanggaran tata aturan dalam pembuatan karya ilmiah. Meskipun daftar yang lengkap tentang tindakan yang dapat dikategorikan sebagai misconduct dalam penelitian tidak ada karena berbagai alasan, tetapi berbagai regulasi yang mengatur batas-batasnya tersedia di berbagai sumber dari berbagai kalangan masyarakat ilmiah. Salah satu yang cukup serius adalah kesalahan yang dikategorikan sebagai "violation of intellectual property", yang mencakup berbagai tindak pelanggaran seperti tidak mencantumkan pihak-pihak yang berkontribusi, secara sengaja membuat sitasi yang keliru, mengklaim hak authorship dan bagian-bagiannya (Salathe, 2008). Bagi masyarakat ilmiah, tindakan plagiasi kemudian dianggap sebagai tindakan yang tercela, dan pelakunya dapat dikenai sanksi yang tentu saja akan merugikan yang bersangkutan di masa masa yang akan datang.

\section{Penelitian Tentang Plagiasi}

Plagiarisme adalah isu besar yang sudah sekian lama berdengung dalam dunia pendidikan tinggi. Dalam literatur menulis dalam bahasa kedua/asing, istilah plagiarisme selain digunakan secara terus menerus untuk menggambarkan kebutuhan akan kesadaran informasi dari berbagai latar belakang yang 
menghasilkan penulis Bahasa Kedua/Asing yang sah, juga menjadi topik penelitian yang menarik. Mengingat sifat terapan dari sebagian besar penelitian menulis dalam bahasa ke dua/ asing, Pecorari dan Petric (2014) mencoba mencari hubungan antara plagiarisme tekstual dan intervensi pedagogis untuk mengatasinya. Mereka menemukan bahwa ketidakjelasan sumber yang bisa diterima dan serangkaian tekanan pada penulis bahasa ke dua/asing menjadi penyebab utama di samping faktor budaya dan media elektronik. Sementara itu, Anney dan Atanas (2015) menginvestigasi plagiarisme di negara berkembang dan menemukan bahwa instruktur atau guru sering mengabaikan tindakan ini yang berakibat pada menjamurnya budaya plagiarism. Di samping karena ketiadaan software pendeteksi plagiarisme, belum adanya aturan tegas yang mencegah dan melarang plagiarisme juga menjadi faktor bagi berkembangnya permasalahan ini. Membandingkan mahasiswa China dan Australia, Ehrich, dkk (2016) juga mendapati bahwa terlepas dari latar belakang etnis para mahasiswa S-1 perguruan tinggi di kedua negara, kurangnya pengetahuan akan plagiarism dan perilaku plagiat menjadi isu yang perlu diperhatikan.

Plagiasi bisa terjadi karena kesengajaan, yang disebabkan oleh keinginan yang melampaui kemampuan, atau karena ketidaktahuan. Melalui kegiatan yang terstruktur dan dilakukan dengan perencanaan yang baik, tindak plagiasi tentu dapat dikurangi. Mata kuliah writing hendaknya dapat menjadi pintu masuk untuk mencegah terjadinya plagiasi. Apabila tidak ada kontrol yang kuat terhadap timbulnya gejala plagiasi, sebenarnya mata kuliah menulis pula yang menjadi ajang pelatihan melakukan plagiasi. Banyaknya tugas menulis, sebagian merupakan topik yang cukup menantang, mendorong sebagian mahasiswa menjadi mudah tergelincir melakukan plagiasi dalam segala bentuknya. Memasukkan muatan anti-plagiasi sebagai tema penulisan atau bahan diskusi untuk dasar pembatan tulisan, misalnya, dapat menjadikan mahasiswa mengetahui tentang aturan-aturan dalam penulisan.

Dengan cara ini, nilai nilai dan norma atau kode etik menjadi terinternalisasi, dan ke- cenderungan untuk melakukan plagiasi secara sengaja dapat dikurangi. Melatihkan cara-cara yang benar untuk melakukan pengutipan langsung, pengutipan tidak langsung, pembuatan rangkuman, dan mencantuman sumber yang benar akan dapat mengurangi kesalahan karena ketidaktahuan atau ketidaksengajaan.

Dengan secara sengaja memasukkan muatan tentang plagiasi dan segala aktivitas penulisan yang melatihkan keterampilan menulis yang menghindari batas plagiasi, mata kuliah Writing dan matakuliah-matakuliah lain yang menuntut mahasiswa membuat tulisan dapat menjadi garda terdepan dalam menanamkan sikap anti-plagiasi. Oleh karena itu, langkah menghindari atau mengurangi intensitas plagiasi dapat dilakukan dengan memasukkan tema plagiarisme dalam kegiatan penulisan.

\section{Faktor-Faktor Penyebab Terjadinya Pla- giasi}

Ada dua sasaran penting yang diungkap dalam paper ini, yaitu (1). faktor penyebab terjadinya plagiasi dan (2) deskripsi penanaman perilaku anti-plagiasi bagi mahasiswa. Untuk mengawali itu, selain diberi task awal untuk melakukan penulisan yang membutuhkan pencantuman sumber atau pemikiran orang lain di dalamnya, disusun kuesioner yang memfokuskan pertanyaan partanyaannya pada beberapa aspek utama. Kuesioner ini adalah sebagai berikut (Tabel 1).

Dari hasil kuesioner dan pengukuran pengetahuan awal didapatkan bahwa ternyata penyebab timbulnya gejala plagiasi dalam tulisan mahasiswa adalah sebagai berikut.

1. Mahasiswa tidak mengetahui ada berbagai jenis dan model pengutipan referensi $(90 \%)$, sedangkan yang $10 \%$ mengaku mengetahui tapi tidak terlalu memahami batas batas yang diperbolehkan untuk tiap jenisnya,

2. Sebagian besar Mahasiswa masih mencampuradukkan aturan tentang quoting, paraphrasing, dan summarizing yang berakibat terjadinya plagiasi $(70 \%)$,

3. Mahasiswa mengenal hanya satu cara melakukan pengutipan frasa atau kalimat intisari pemikiran orang lain, yaitu dengan menuliskan seperti sumber aslinya $(90 \%)$, 
Tabel 1. Aspek pengamatan dan kuesioner pengetahuan tentang tatacara pengutipan

\begin{tabular}{lcl}
\hline \multicolumn{1}{c}{ Aspek } & Nomor & \multicolumn{1}{c}{ Butir amatan } \\
\hline & 1 & Pengetahuan tentang jenis-jenis kutipan yang dipakai \\
Aspek pengetahuan & 2 & Pengetahuan tentang kutipan langsung (quotation) \\
& 3 & Pengetahuan tentang kutipan tidak langsung \\
& 4 & Pengetahuan tentang parafrase (paraphrase) \\
& 5 & Pengetahuan tentang rangkuman (summary) \\
Kemampuan mengamati & 7 & Kutipan melebihi jumlah maksimal yang diperbolehkan \\
& 8 & Bentuk paraphrase yang tidak sesuai \\
& 9 & Penulisan nama yang tidak sesuai kaidah \\
Kemampuan mengutip & 10 & Penggunaan kosakata asli sumber dalam rangkuman \\
& 11 & Membuat kutipan (quotation) \\
& 12 & Memparafrase \\
& 13 & Merangkum \\
\hline
\end{tabular}

4. Sebagian mahasiswa menganggap mencantumkan nama pemilik gagasan adalah tidak mutlak atau bukan keharusan $(65 \%)$,

5. Semua mahasiswa tidak mampu melakukan pengutipan dengan benar dalam tulisan yang mereka buat sesuai dengan kaidah pengutipan yang berlaku untuk masingmasing jenis,

6. Semua mahasiswa mengetahui istilah dan isu tentang hak paten, hak atas kekayaan intelektual, dan isu plagiasi di dalamnya, tapi hampir semuanya (90\%) tidak menganggap atau tidak mengetahui bahwa mengutip pemikiran dalam tulisan adalah bagian dari hal tersebut.

Dari hasil kuesioner dan pengamatan serta diikuti wawancara untuk menggali jawaban lebih dalam, dapat disimpulkan bahwa memang isu plagiasi dan segala tata aturan yang melingkupinya masih belum diketahui oleh sebagian besar mahasiswa. Mereka tidak menyadari bahwa kegiatan mengutip pemikiran orang lain merupakan suatu isu serius dalam membangun kesadaran anti-plagiasi di kalangan mereka.

Mahasiswa masih mengalami beberapa perrmasalahan yang berkaitan dengan peraturan yang kurang jelas dan pemberian contoh yang kurang lengkap tentang tatacara pembuatan kutipan ini. Dalam Buku Panduan Penulisan Tugas Akhir Skripsi FBS UNY, misalnya, contoh kutipan yang diberikan masih kurang lengkap, yang kemudian berakibat kurangnya data yang memungkinkan mahaiswa melakukan penyimpulan sendiri atas tatacara pengutipan. Yang tersaji di buku panduan berbahasa Indonesia tersebut sebenarnya cukup lengkap, yang membagi jenis kutipan menjadi dua kelompok, kutipan langsung dan kutipan tidak langsung. Sayangnya dalam setiap contoh itu kurang terpaparkan secara eksplisit bagaimana proses membuatnya. Tidak ada ketentuan yang mengharuskan dilakukannya paraphrase atas pernyataan atau kalimat di sumber asli, misalnya, yang didampingkan dengan hasil memparafrase sumber. Sebenarnya, apabila contoh yang diberikan di buku itu diperjelas dengan proses memparafrase, mahasiswa akan banyak terbantu dalam melakukan kutipan.

\section{Langkah-Langkah Pengembangan Sikap Anti-Plagiasi}

Langkah langkah tindakan yang dilakukan adalah dengan cara merumuskan rencana atau rancangan tindakan, mengimplementasikan dalam kegiatan pembelajaran di kelas serta melakukan observasi atas pelaksanaanya, dan melakukan refleksi atas pelaksanaanya. Ada 2 siklus tindakan, dengan siklus yang ke dua merupakan rangkaian kegiatan yang berupa penyempurnaan dari siklus sebelumnya.

Siklus Pertama dilakukan dengan diawali rencana berdasar keadaan dalam assessment awal. Mahasiswa yang diberi task untuk melakukan penulisan esai argumentatif yang di dalamnya harus mencantumkan kutipan dari berbagai sumber ternyata melakukan berbagai penyimpangan dari tatacara pengutipan yang dibenarkan, yang umumnya dilakukan dengan cara langsung mengutip apa adanya tanpa melakukan pengubahan redaksional atau mengganti kosakata, padahal kutipan tersebut masuk ke dalam tubuh paragraf dan mengesankan 
seakan akan itu adalah pemikiran si mahasiswa sendiri, dan sebagian mencantumkan sumber berupa nama dan tahun penerbutan sumber. Meskipun mencantumkan sumber, ini merupakan salah satu bentuk plagiasi juga, karena tidak membedakan atau mencampuradukkan antara kutipan langsung dan tidak langsung.

Pelaksanaan tindakan dilakukan mengikuti tahapan perkuliahan Writing sesuai dengan silabus, hanya saja didahului dengan pembahasan tentang tatacara pengutipan yang benar dari ketiga jenis atau model yang bisa dilakukan di atas, diikuti dengan praktik langsung di dalam kelas. Dalam penelitian ini, tahap ini diberi nama tahap penanaman pengetahuan. Setelah tahap penanaman pengetahuan, kemudian dilakukan tahap implementasi dan internalisasi aturan.

Langkah yang dilakukan dalam siklus ini secara ringkas adalah (1). pengembangan pengetahuan tentang quotation dan disertai latihan-latihan terstruktur, mulai dari mengidentifikasi atau membedakan sampai membuat sendiri kutipan sesuai kaidah yang benar, diikuti cara melakukan paraphrase disertai dengan latihan membedakan paraphrase dan quotation, mengidentifikasi paraphrase yang benar dan tidak benar, dan kemudian berlatih melakukan paraphrase sendiri, dan terakhir melakukan praktik membuat summary, dan (2) mempraktikkan pengetahuan yang diperoleh dalam melakukan penulisan essay. Karena setiap essayyang ditulis memerlukan waktu setidaknya 3 minggu untuk membahas dan melakukan revisi, sepanjang hampir satu semester perkuliahan hanya dilakukan penulisan essay sejumlah 4 macam tulisan, karena ada beban tambahan membahas khusus bagian pengutipan sumber di samping aspek kualitas penulisan yang lain seperti organisasi paragraf, tata bahasa, kosa kata, piranti kohesi, dan sebagainya. Sebagai tambahan, sumber asli yang dikutip dalam tulisan harus disertakan dalam bentuk teks asli yang ditulis ulang atau difotokopi sebagai bukti bahwa mahasiswa telah leaksanakan pengutipan secara sah dan tidak melanggar batas batas yang sudah diatur dalam kaidah penulisan karya ilmiah.

Refleksi siklus pertama nenunjukkan beberapa hal, yang intinya adalah bahwa

a. Tugas tugas penulisan mulai menunjukkan bahwa mahasiswa memahami tatacara pengutipan yang menggunakan 3 model berbeda tersebut.

b. Masih ada pencampuradukan cara pengutipan, terutama dalam hal melakukan paraphrase yang masih sangat mirip dengan bentuk aslinya, dan bukan mengikuti kaidah paraphrasing yang benar: ide sama tapi seharusnya dinyatakan dalam bentuk lain atau dalam bahasa sendiri.

c. Mahasiswa masih belum menyadari arti penting melakukan pengutipan yang benar dalam kaitannya dengan menghormati hak pemikiran atau karya orang lain, atau dengan kata lain isu anti-plagiasi masih belum tertanam dalam diri.

d. Perlu dilakukan siklus berikutnya yang diawali dengan membahas isu plagiasi dan diikuti dengan praktik penulisan yang mendekati situasi sebenarnya, yaitu menulis proposal penelitian sebagai salah satu bentuk karya ilmiah yang di dalamya tentu saja sarat dengan berbagai aturan, termasuk di antaranya adalah isu-isu plagiasi dalam penulisan karya. Kebetulan mahasiswa dalam kelas yang sama masih melanjutkan perkuliahan di Introduction to Educational Research. Siklus ke dua dilanjutkan di mata uliah baru ini.

Siklus ke dua diawali dengan pembahasan kembali tentang isu plagiasi, antara lain dengan penayangan berbagai konsensus peneliti dan penelitian atau aturan universal tentang plagiarism dan efek serta resikonya bagi integritas pelaku dan bagi perkembangan dunia ilmu pengetahuan pada umumnya. Dibahas juga peraturan universitas yang tertuang dalam Buku Saku Panduan Antiplagiarisme (Nurgiyantoro, dkk: 2012).

Mahasiswa kemudian melakukan analisis terhadap contoh-contoh yang diberikan, berupa beberapa bagian dari paper dan karya ilmiah yang mencantumkan kutipan. Beberapa lembar contoh pengutipan yang baik atau baku ini diberikan pada mahasiswa, dan tugas pertama mereka adalah mencari kalimat atau referensi asli yang dikutip oleh penulis paper tersebut. Setelah ditemukan sumber aslinya, mahasiwa bertugas membandingkan kedua bentuk ini. Paragraf atau kalimat asli yang ada di buku atau paper sumber didampingkan dengan versi 
kutipan yang dibuat oleh penulis paper yang dijadikan contoh ini, dan mulai dilakukan diskusi untuk melakukan reka ulang proses pengutipan yang dilakukan.

Sebagai bahan untuk melakukan justifikasi atas proses pengutipan yang terjadi di paper contoh, dibahas terbagai contoh dan peraturan tentang tatacara melakukan pengutipan, yang dalam bahasa Inggris terkategori menjadi 3 model: paraphrase, quotation, dan summary. Masing masing model dicoba dilakukan, dengan satu paragraf sumber dirubah menjadi 3 model yang berbeda itu, disertai conton non-contoh berupa model pengutipan yang tidak memenuhi kaidah pengutipan yang baik sebagai bahan perbandingan lebih lanjut.

Setelah itu, mahasiswa langsung berpraktik melakukan pengutipan yang dilakukan dalam proposal penelitian yang mereka buat di perkuliahan Introduction to Educational Research. Dengan langsung melakukan penulisan karya ilmiah, utamanya dalam bab yang banyak membutuhkan kutipan, yaitu bab II. Theoretical Description, mahasiswa dapat langsung berpraktik sesuai dengan situasi yang sebenarnya.

Pembahasan tentang isu plagiasi dilakukan dengan memberi contoh contoh nyata tindakan plagiasi yang dilakukan oleh oknum anggota masyarakat ilmiah, termasuk di perguruan tinggi, sehingga setidaknya hal ini akan dapat membangkitkan semangat untuk tidak mengikuti perbuatan tidak sesuai atata aturan penulisan karya ilmiah tersebut. Dengan demikian memang amatan utama adalah pada penanaman sikap antiplagiasi yang nantinya tercermin pada tulisan mahasiswa. Perkuliahan dan pembahasan tentang isu plagiasi dilakukan dengan menugaskan mahasiswa berkelompok melakukan prsentasi tentang definisi plagiasi, contoh plagiasi, perbandingan plagiasi dan nonplagiasi dalam pengutipan sumber atau pendapat orang lain.

Kemudian penulisan mini proposal penelitian dilakukan dengan fokus amataan dan pembahasan pada pembuatan bagian deskripsi teoritik, yang kemudian data dikumpulkan dari sejauhmana pengutipan dilakukan dengan benar dan tidak melanggar ketentuan pencantuman pendapat orang lain.
Dalam mini proposal yang menjadi tugas perkuliahan, mahasiwa diwajibkan membuat kutipan dari berbagai sumber dalam berbagai model pengutipan yang dibolehkan (paraphrase, quotation, dan summary). Mahasiswa juga wajib menyertakan sumber asli yang dikutip sehingga dapat dilacak dengan mudah, apakah pengutipan yang dilakukannya ada indikasi pelanggaran atau tidak.

Ada dua hal yang tercakup dalam siklus ini, pertama adalah membuat responden memahami peraturan dan tatacara pengutipan, dan ke dua adalah praktik pengutipan yang dilakukan mengiringi diskusi tentang berbagai versi pengutipan, baik yang benar maupun yang melebihi ketentuan yang diperbolehkan dalam melakukan pengutipan.

Dalam analisis yang dilakukan terhadap contoh yang diambil dari jurnal atau paper yang sudah diterbitkan di majalah ilmiah bereputasi dan dari berbagai jurnal yang terbit secara internasional, mahasiswa diajak untuk melacak bagaimana versi kutipan itu berbeda - dan artinya tidak melanggar batas definisi plagiasi- dengan bentuk tulisan di naskah sumber yang menjadi referensinya. Mereka kemudian menuangkan kemampuan melakukan pengutipan dalam proposal karya mereka sendiri. Dengan kweajiban meyertakan copy naskah asli yang menjadi sumber kutipan, dilakukan analisis bersamasama di dalam kelas, yang hasilnya menunjukkan bahwa sebagian besar sudah terhindar dari gejala melakukan plagiasi.

\section{Diskusi}

Beberapa temuan awal yang dihasilkan menunjukkan bahwa memang mahasiswa secara umum tidak mengetahui dengan persis bagaimana pengutipan pendapat orang lain yang sah atau legal dilakukan dalam karya mereka. Ketidaktahuan ini berujung apada terjadinya berbagai pelanggaran atas regulasi mengenai pengutipan buah pikiran orang lain secara sah. Sebenarnya, dalam dunia ilmiah, menurut Salathe (2008), tidak ada alasan bahwa terjadinya pelanggaran maupun misconduct dalam penelitian itu adalah karena ketidaktahuan. Siapapun yang memasuki dunia ilmiah, termasuk di antaranya adalah pelaporan hasil penelitian dan diseminasinya, 
harus mengetahui aturan yang berlaku di kalangan masyarakat ilmiah.

Tahapan yang dilakukan untuk menanamkan sikap anti-plagiasi ini dilakukan dalam 2 sisi yang dilakukan secra kronologis dan simultan. Tahap pertama adalah tahap penanaman pengetahuan, yang dilakukan mulai dari dikusi definisi, diskusi contoh, dan analisis tentang contoh yang diberikan, baik contoh baik maupun contoh non-contoh. Tahap berukitnya adalah tahap implementasi dan internalisasi. Tahap ini dilakukan dengan praktik melakukan penulisan dan pengutipan yang sesuai dengan kaidah penulisan yang tidak melanggar regulasi.

Hasil analisis menunjukkan bahwa untuk 3 jenis cara pengutipan yang rentan terhadap tindak plagiasi adalah melakukan paraphrase, yaitu sejenis kutipan tidak langsung dari sumber yang seharusnya dilakukan dengan melakukan perubahan atas kalimat asli di sumber menjadi kalimat dengan isi sama tapi diungkapkan dengan bahasa sendiri, tapi dilakukan dengan cara seperti melakukan quotation (kutipan langsung), yang hanya berupa menulis ulang kalimat atau peryataan seperti aslinya. Hali ini dilakukan terutama karena memang untuk melakukan paraphrase perlu dilakukan usaha yang lebih, karena membutuhkan penggantian kosakata dan mungkin struktur kalimat dengan tanpa mengubah inti atau makna. Karena kutipan langsung dilakukan dengan mengutip kalimat seperti aslinya dan dengan tanda tertentu (tanda kutip), tentu hal ini lebih mudah dilakukan dibanding melakukan paraphrase.

Melakukan tindakan melalui serangkaian kegiatan aktif memparafrase atau membuat summary ternyata cukup efektif membuat mahasiswa memiliki kemampuan terhindar dari plagiasi, namun dirasakan bahwa masih ada yang perlu dilakukan. Dalam tindakan di Siklus 2 dilakukan analisis atau pelacakan ulang bagaimana pengutipan telah dilakukan oleh pihak pihak yang dianggap berkompeten dan professional. Hal ini terbukti sangat membantu mahasiwa dalam melakukan pengutipan. Dalam kegiatan pelacakan ulang ini yang dilakukan adalah mencoba melacak ulang sumber asli dari bahan yang dikutip di paper contoh, dan setelah sumber asli ditemukan, ternnyata banyak hal yang bisa dipelajari. Mahasiswa dapat membandingkan dua versi pemikiran itu, yaitu pemikiran asli seperti tertulis di sumber, dengan pemikiran yang sudah dikutip secara sah oleh penulis berpengalaman tadi. Bagaimana paraphrase dilakukan, model kalimat yang berubah, penggantian kosa kata, dan semacamnya, yang membuat hasil kutipan tetap ememiliki makna atau maksud yang sama dan dinyatakan secara berbeda. Latihan intensif yang dilakukan mengikuti model bedah kutipan ini kemudian diikuti dengan praktik mengikuti seperti yang dilakukan oleh para penulis dalam contoh tersebut.

Di akhir tindakan, terungkap bahwa kesadaran tentang perlunya mengutip secra benar sudah terbentuk, dan mahasiswa juga memiliki pemahaman tentang betapa tinndakan melakukan plagiasi ini merupakan perbuatan tercela di ranah akademik, bahkan pelaku bisa terseret ke dalam urusan yang lebih serius dari pada sanksi moral atau sanksi akademik, misalnya sampau terjasi urusan pidana. Kesadaran ini masih perlu dipupuk terus dan disertai hadirnya perangkat pengaturan yang jelas, sehingga pemahanan ini tidak menajdi luntur kembali gara gara tidak adanya regulasi yang lebih ketat terhadap praktik kecurangan akadmik di masa yang akan datang.

\section{SIMPULAN}

Penelitian ini dilakukan untuk membentuk sikap dan perilaku anti-plagiasi yang tercermin di dalam tulisan mahasiswa ketika membuat essay dan dilanjutkan menulis proposal penelitian terutama pada bagian deskripsi teoretik. Hasil menunjukkan hal berikut ini.

1. Mahasiswa secara umum tidak memahami cara membuat kutipan yang benar (kutipan langsung dan tidak langsung), bahkan sebagian tidak mengetahu bahwa ada regulasi yang mengatur hal ini.

2. Mahasiswa tidak menyadari bahwa definisi plagiasi bukan hanya berupa mengambil karya orang lain secara utuh dan mengakuinya sebagai karya sendiri, tapi juga berupa pencantuman pemikiran mulai dari sepenggal frase, satu kalimat, sampai satu atau beberapa paragraf yang bersumber dari pemikiran orang dan mencantumkannya secar tidak sah dalam tulisan sendiri. 
3. Langkah membahas teknik pengutipan telah membuat mahasiswa mampu mengurangi kecenderungan plagiasi dalam tulisan essay mereka. Langkah ini berupa penanaman pemahaman awal tentang berbagai regulasi dalam pengutipan pikiraan atau gagasan orang lain ke dalam tulisan sendiri secara benar, namun masih diperlukan langkah sistematis berikutnya agar pengetahuan ini terinternalisasi dalam diri dan menjadi kemampuan aktif yang dimiliki oleh responden.

4. Rekonstruksi pengutipan sebagaimana yang ada di dalam jurnal bereputasi tingkat internasional yang diambil sebagai contoh, dengan diikuti langkah melakukan analisis pembandingan antara bentuk terkutip dengan bentuk asli yang ada di naskah sumber kutipan, serta melakukan aktivitas mekanistis berbentuk menulis ulang kedua versi pemikiran telah mampu membuat responden memiliki sense dan kesadaran tentang betapa pengutipan yang ceroboh telah membawa pada situasi plagiasi yang merugikan semua pihak.

5. Tulisan terindikasi berbau plagiasi menurun secara tajam secara kuantitatif, dari $85 \%$ dari total jumlah tulisan (17 tulisan) menjadi $40 \%$ di akhir siklus 1 (8 tulisan), dan akhirnya semakin mengecil (20\%, 4 tulisan) seiring dengan diketahuinya cara yang benar dan pemahaman akan hakikat plagiasi dan akibatnya bagi integritas mereka sebagai akademisi.

6. Perilaku plagiasi dalam penulisan essay dan proposal penelitian diindikasikan terjadi karena tidak diketahuinya peraaturan yang berkaitan dengan plagiasi dan kurangnya kesempatan praktik secara terbimbing dalam penulisan essay. Dalam kurikulum pembelajaran bahasa Inggris program S1 nampaknya perlu dicantumkan secara ekplisit perlunya pembahasan isu plagiasi dalam karya tulis.

\section{DAFTAR PUSTAKA}

Anney, V. N., \& Atanas, M. M. (2015). Student's Plagiarisms in Higher Learning Institutions in the Era of Improved Internet Access: Case Study of Developing Countries. Journal of Education and Practice. Vol. 6 No. 13.

Bailey, S. (2011). Academic Writing: A Handbook for International Students. New York: Routledge.

Dong, T., \& Yue, L. (2015). A Study on Critical Thinking Assessment System of College English Writing. English Language Teaching, 8 (11), 176.

Hjortshoj, K. 2009. The Transition to College Writing (2nd ed.). Boston: Bedford/St. Martins.

Menary, R. 2007. Writing as Thinking. Language Sciences, 29(5), 621-632.

Nurgiyantoro, B. dkk. 2014. Buku Saku Panduan Antiplagiarisme. Yogyakarta: FBS UNY.

Oatley, K., \& Djikic, M. 2008. Writing as Thinking. Review of General Psychology, 12(1), 9.

Pecorari, D., \& Petrić, B. (2014). Plagiarism in Second-language Writing. Language Teaching, 47(03), 269-302.

Salathe, M. (Ed.), (2008). Integrity in Scientific Research: Principles and Procedures. Bern: Swiss Academies of Arts and Sciences. 